\title{
Automatic Liquefied Petroleum Gas Leakage Control System Using Proportional Integral Derivative (PID)
}

\author{
Haryanto ${ }^{1}$, Achmad Fiqhi Ibadillah ${ }^{2}$, Umar Faruq ${ }^{3}$ \\ Faculty of Engineering \\ University of Trunojoyo Madura \\ Bangkalan, Indonesia \\ 1'haryanto@trunojoyo.ac.id, ${ }^{2}$ fiqhi.achmad@gmail.com, \\ ${ }^{3}$ umarfaruq050195@gmail.com
}

\author{
Lilik Anifah ${ }^{4}$ \\ Informatics Department \\ Universitas Negeri Surabaya \\ Surabaya, Indonesia \\ ${ }^{4}$ lilikanifah@unesa.ac.id
}

\begin{abstract}
Along with the development of technology and information, human needs toward kerosene stove in household sector change over to Liquefied Petroleum Gas (LPG) stove, which is cheaper and more effective. However, the use of LPG stove should consider precised procedures as the gas is easy to explode. One of some causes of gas explosion and burn is when people forget to turn off the stove while cooking and an existing gas leak. To address such human errors, a microcontroller-based tool needs to be developed to ably detect a gas leak and control the gas stove automatically. Equipped with a stepper motor, the tool can regulate the gas flow and the stove temperature. The tool also has a buzzer as a gas leak indicator and an LCD used to display the detection results from the MQ6 sensor. The MQ6 sensor is used as a gas detection and thermocouple sensor to identify the stove temperature that will be displayed in the seven segments. The gas stove's automatic control uses Proportional Integral Derivative (PID) method that can make precised valve opening angel of the stepper motor. The result of this research is expected to troubleshoot gas explosion and burn problems caused by the LPG stove.
\end{abstract}

Keywords-Microcontroller; MQ6; Motor Stepper; PID

\section{INTRODUCTION}

Gas sensor technology has been used in several studies. Detection of gas NH3 and H2S through sensor MQ-137 and MQ-136 overcome the harmful excess gas on the farm specially hazard for cow health [1]. Measuring the shale gas content helps to improve the accuracy of shale gas resource assessment, and obtain an unattended shale gas metering system [2]. The infrared leak detection technology can detect and locate the gas leakage using of SF6 equipment [3]. Embended system using MQ-9 chemical sensor investigated, the aim of this system in order to detect dangerous gas specially hydrocarbon [4].

Since the removal of subsidies on kerosene by Indonesian government, many people began to use Liquefied Petroleum Gas (LPG) cylinders for daily use. However, there are still numbers of people especially in rural areas who use kerosene for certain rationales. For instance, they are reluctant to use LPG because they might not be able to afford it as it is slightly more expensive compared to that of kerosene. They are also afraid because LPG has a big possibility to explode in sudden times. As a technical matter, they lack of knowledge in operating the procedures such as installing and removing the regulator hoses, checking the hoses condition, and indicating the existing gas leak.

In addition, the unavailability of the prevention procedures given by Indonesian government regarding the case addressing a gas leak makes people more frightened to use LPG. Actually, an early prevention of gas explosion can be indicated through the presence of gas leak. However, not so many people understand the indicators of existing gas leak. Along with the development of technology, a security system is developed by creating automatic control and protection system toward a gas leak phenomenon in LPG cylinders case. By the presence of this tool, people can know easily some indicators of a gas leak.

Liquefied Petroleum Gas Leakage Control System has been investigated several researchers. Gas leakage is detected the sensor then detect the leakage, an alert message will be sent to the certain person related to the gas leakage [5]. Improvement on gas leakage detection and location system based on wireless sensor network for various gas has been investigated [6]. Liquefied Petroleum Gas detection and control integrated with communication between the microcontroller and the GSM proven has been solving the LPG leakage [7]. However [5,6] still not specific discuss about LPG but various gas, while [7] not yet researching about how controlling the leakage using control system.

The purpose of this research is to solve this problem by design and implement automatic liquefied petroleum gas leakage control system using PID. Generally, the development of the aforementioned system is to help people early prevent a gas leak problem. Further, they can live safer because they know early the cause of gas explosion and burn.

\section{THEORY}

\section{A. Microcontroller}

Microcontroller is a complete computer in a form of a small chip containing ROM (Read-Only Memory), RAM (Read-Write Memory), DAC (Digital to Analog Converter) and communication serial. Among other types, AVR 
microcontroller has been widely used today. There are many types of it such as ATmega16, ATmega8, and ATmega32. To be able to program the ATmega16 microcontroller, one might use Code Vision software in which the programming language uses language $\mathrm{C}$ that lays between a high level programming language and the Assembly. ATmega16 basically has four different Ports namely Port A, B, C, and D. There are 8 pins in each port that can be operated when programming an electronic tool (see Figure 1)[5].

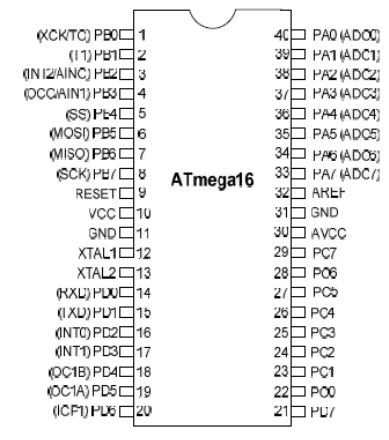

Fig. 1. . Datasheet of Atmega16

MQ6 is a type of gas sensors functioning as a detector for LPG, of which containing of propane and butane compounds. The difference between MQ6 and other sensors is at the sensitivity capability. The more expensive the sensor, the better its sensitivity. Among other gas sensors such as MQ2, MQ5, TGS2610, and AF30, MQ6 sensor can detect a gas presence from 200 to $10.000 \mathrm{ppm}$. This typical sensor has a high sensitivity level and a fast detecting process. This sensor only needs 5 Volt to run. Figure 2 shows how MQ6 sensor looks.

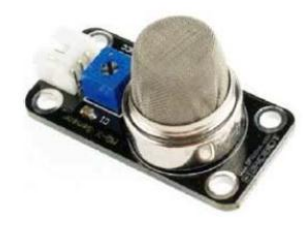

Fig. 2. The shape of MQ6 gas sensor

\section{B. Thermocouple Sensor}

Thermocouple sensor acts as a temperature detector that consists of two different conductors named thermo-elements. Each conductor is isolated but not at the junction point. There are several types of thermocouple that can be drawn as follows:

1. Type $\mathrm{B}$ can measure temperature ranging from $100^{\circ} \mathrm{C}$ to $1800^{\circ} \mathrm{C}$.

2. Type $\mathrm{E}$ can measure temperature ranging from $270^{\circ} \mathrm{C}$ to $+790^{\circ} \mathrm{C}$.
3. Type $\mathrm{J}$ can measure temperature ranging from $-40^{\circ} \mathrm{C}$ to $750^{\circ} \mathrm{C}$.

4. Type $\mathrm{K}$ can measure temperature ranging from from $200^{\circ} \mathrm{C}$ to $+1200^{\circ} \mathrm{C}$

5. Type $\mathrm{N}$ can detect temperature ranging from $-260^{\circ} \mathrm{C}$ to $1300^{\circ} \mathrm{C}$.

6. Type $\mathrm{R}$ is less sensitive to the inputs, but can measure temperature up to $1600^{\circ} \mathrm{C}$.

7. Type $\mathrm{S}$ can detect temperature ranging from $-50^{\circ} \mathrm{C}$ to $1760^{\circ} \mathrm{C}$. This type of thermocouple sensor is more expensive compared to other types.

8. Type $\mathrm{T}$ can detect temperature ranging from $0^{0} \mathrm{Cto}$ $300^{\circ} \mathrm{C}$.[8]

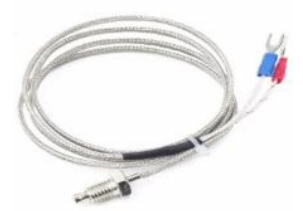

Fig. 3. Thermocouple sensor Type K

\section{Proportional-Integral-Derivative Controller}

Proportional-Integral-Derivative (PID) controller is a combination between three types of controller namely proportional, integral-proportional and derivative-proportional controllers. If the three controllers work separately, they might work not good because each controller has its own advantages and disadvantages.

Proportional controller is a linear reinforcement whose gain can be adjusted. The relationship between output $m(t)$ and error signal e (t) can be formulated as follows:

$$
\begin{gathered}
\mathrm{m}(\mathrm{t})=\mathrm{Kp} \mathrm{e}(\mathrm{t}) \\
\mathrm{Kp}: \text { Gain proportional } \\
\mathrm{m}(\mathrm{t}): \text { Controller output } \\
\mathrm{e}(\mathrm{t}): \text { Error signal }
\end{gathered}
$$

Integral-proportional controller is a transformation from the integral control output $\mathrm{m}(\mathrm{t})$, changing with the same time function along the error signal. The relationship between the controller output $\mathrm{m}(\mathrm{t})$ and the error signal $\mathrm{e}(\mathrm{t})$ can be equated as follows:

$$
\begin{aligned}
\mathrm{m}(\mathrm{t}) & =\mathrm{K}_{\mathrm{p}} \cdot \mathrm{e}(\mathrm{t})+(\mathrm{t}) \mathrm{dt} \\
& =\mathrm{K}_{\mathrm{p}} \cdot \mathrm{e}(\mathrm{t})+\frac{\mathrm{K}_{p}}{T_{i}} \int_{0}^{\tau} e(t) d t
\end{aligned}
$$

$$
\begin{aligned}
& K_{p} \text { : Gain proportional } \\
& T_{i} \text { : Time derivative provisions }
\end{aligned}
$$

Derivative controller can also be called as a rate controller because the controller output is the same as the change in error signal. When the lapse time $\mathrm{Td}$ is the time interval of the progressive proportional controller's responses affected by the 
action rate, the constant time $\mathrm{Ti}$ adjusts the action of the integral control while $\mathrm{Kp}$ strengthens the proportional or integral part of the action control.

$$
m(t)=K_{p} \cdot e(t)+K_{p} \cdot T_{d} \frac{\partial e(t)}{\partial t}
$$

\section{$\mathrm{K}_{\mathrm{p}}$ : Gain proportional}

\section{$\mathrm{T}_{\mathrm{d}}$ : Time derivative provisions}

The combination between proportional, integral, and derivative controllers are known as the PID method. This PID method has the advantage in correcting signal errors compared to each of the three controllers. The PID control equation can be given as follows:[7]

$$
\mathrm{m}(\mathrm{t})=\mathrm{K}_{\mathrm{p}} \cdot \mathrm{e}(\mathrm{t})+\frac{\mathrm{K}_{p}}{T_{i}} \int_{0}^{\tau} e(t) d t+\mathrm{K}_{\mathrm{p}} \cdot \mathrm{T}_{\mathrm{d}} \frac{\partial \mathrm{e}(\mathrm{t})}{\partial \mathrm{t}}
$$

\section{Liquid Cristal Display (LCD)}

Liquid Cristal Display (LCD) is one of the electronic components that serves to display dataeither characters, letters or graphics. It consists of 16 pins, one of which functions as a display contrast controller. The LCD display (Figure 4) is available in a moduleform that consists of the LCD display itself and its supporting circuit including ROM.

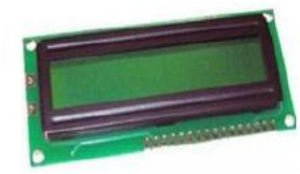

Fig. 4. The shape of LCD

\section{METHODS}

The system designed in this research wasan automatic stove and leaking gas detection using the electronic componentsnamely MQ6 gas sensor to detect a gas leak and a thermocouple sensor to detect a cooking temperature. This system, moreover,was divided into two processes namely the leaking gas detection process and the cooking temperature detection process in which all results will be displayed on LCD and the seven segments. This study used the following methods:

\section{Quantitative}

Revealing supporting theories or previous studies aimed to make a research on an automatic stove and gas detector function as well as possible.

2. Observation

Registering the used tools and systems aimed to get the analysis results and conclusions regarding the tools and systems.

3. PID Method

PID method functioned as a controller of a gas flow on a gas valve to the stove.

4. Designing Method of the Hardware

The method to design the hardware was a stage to assemble parts into a hardware device, such as wiring and soldering the seven segment which required additional resistor components.

5. Designing Method of the Software

Software design consisted of several programs or different software uses. The program to be made consisted both food temperature detection program and leaking gas detection program. The software used to program was Code Visio AVR. To enter the program into the microcontroller, an eXtreme Burner AVR software was employed.

According to Figure 5, the design of an automatic control and LPG leakage protection systems in the present research included a gas sensor named MQ6 which functions to detect LPG gas leaks. This system also covereda thermocouple sensor as a temperature sensor used in a gas stove to determine the stove temperature. The undertaken process in the microcontroller program can be explained as follows:

The first process was defining 500 ADC in Code Vision AVR program. If the MQ6 sensor conveyed more than 500 ADC, the LCD would display a sign "Dangerous" and the buzzer would sound indicating an existinggas leak. Otherwise if the ADC value showed less than 500, the LCD would display a sign "Safe" and the buzzer was in the off mode indicatingno gas leak. When there was no gas leak, the next step was determining the temperature set displayed on the seven segments. Then, the thermocouple sensor detected the temperature of the flame on the gas stove. If the thermocouple sensor detecteda temperature overreaching the earlyset point, the stepper motor would rotate to reduce or to increasea gas flow so that the temperature could be stable according to the set point for a minute. Aftera minute, the stepper motor moved to close the gas valve, in which the method used here was PID method.

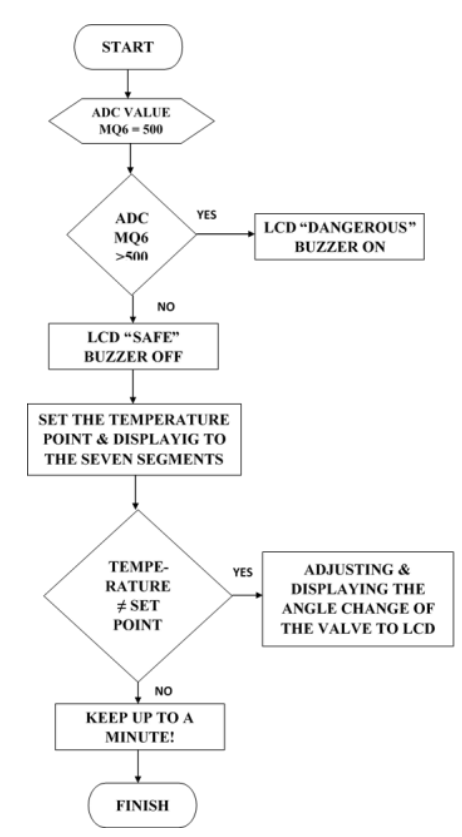

Fig. 5. Whole system algorithm 


\section{RESULTS AND DISCUSSION}

\section{A. MQ6 Sensor Test}

MQ6 sensor test was to reveal how MQ6 sensor was wellfunctioned. Besides, the test was addressed to know the part per million (ppm) value of the gas when leaking.

TABLE I.

\begin{tabular}{|l|l|l|l|l|l|}
\hline No. & \multicolumn{1}{|c|}{ PPM } & ADC & \multicolumn{1}{|c|}{ X } & Total Bit & \multicolumn{1}{|c|}{ Status } \\
\hline 1. & 3052 & 319 & 9.5703125 & 1024 & Safe \\
\hline 2. & 5600 & 585 & 9.5703125 & 1024 & Dangerous \\
\hline 3. & 5128 & 536 & 9.5703125 & 1024 & Dangerous \\
\hline 4. & 4788 & 501 & 9.5703125 & 1024 & Dangerous \\
\hline 5. & 5688 & 594 & 9.5703125 & 1024 & Dangerous \\
\hline 6. & 5400 & 564 & 9.5703125 & 1024 & Dangerous \\
\hline 7. & 4860 & 508 & 9.5703125 & 1024 & Dangerous \\
\hline 8. & 5468 & 571 & 9.5703125 & 1024 & Dangerous \\
\hline 9. & 5380 & 562 & 9.5703125 & 1024 & Dangerous \\
\hline 10. & 5616 & 587 & 9.5703125 & 1024 & Dangerous \\
\hline
\end{tabular}

Table I. concluded that the MQ6 sensor was in a good condition and could be used. The status was influenced by the program that had been determined. For instance, if the ADC value was more than 500, the gas sensor would show a dangerous sign and the buzzer sounded. Meanwhile, if the value was less than 500 ,the sensor would indicate a safe sign (see Figure 6 and 7).

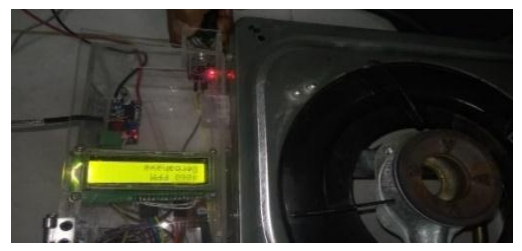

Fig. 6. Dangerous condition

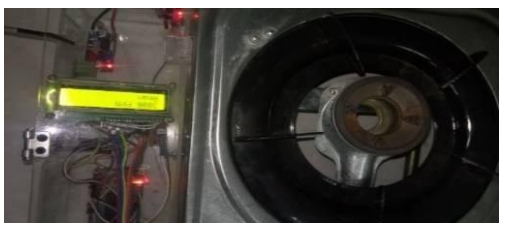

Fig. 7. Safe condition

The way to determine the ppm value couldreferred to the $\mathrm{ADC}$ conversion equation as drawn below:

$$
\mathrm{ADC} \text { conversion }=\frac{\text { Vin }}{\text { Vref }} \times 1024
$$

Vin: Input voltage

Vref: Reference voltage

$$
X=\frac{\text { Range }}{\text { Total Bit }}
$$

For the Analog to Digital Converter (ADC) 10 bits on ATMega16 microcontroller, the resulting output was 2 powers of 10 equal 1024. MQ6 has a detecting range from 200 to
$10000 \mathrm{ppm}$. Based on the seventh equation, so that $\mathrm{X}$ value can be obtained as follows:

$$
\begin{aligned}
& \text { Total Bit }=1024 \\
& X=\frac{\text { Range }}{\text { Total Bit }}
\end{aligned}
$$

$X$ value (9.5703125) was then inputted in the third equation. The ppm measurement in accordance with the MQ6 sensor datasheet started from 200 to $10000 \mathrm{ppm}$. The reference voltage used was $4 \mathrm{~V}$, which was equivalent to $10000 \mathrm{ppm}$. So that, based on equation 2, the increase in X / ppm per 1 bit was equal to 9.5703125 . For example, with the voltage $\mathrm{Vin}=2 \mathrm{~V}, \mathrm{X}=9.5703125$ was inserted to equation 3 to convert to ppm. [9]

$$
\mathrm{ppm}=\mathrm{X} \times \mathrm{ADC} \text { conversion }
$$

\section{B. Thermocouple Sensor Test}

Thermocouple sensor test was done to reveal thermocouple Type-K and know whether the developed program worked well. The thermocouple Type $\mathrm{K}$ worked relevantly to the food thermometer sensor examined as a calibration (see Figure 9). After the test conducted, the thermocouple sensor Type $\mathrm{K}$ as well as the program worked greatly. Table 2 shows the results

\begin{tabular}{|c|c|c|c|c|c|}
\hline \multirow{2}{*}{ No. } & \multirow{2}{*}{ Ingredients } & \multicolumn{2}{|c|}{ Temperature } & \multirow{2}{*}{$\begin{array}{l}\text { Termometer } \\
\text { Temperature }\end{array}$} & \multirow{2}{*}{ Vout } \\
\hline & & $R$ & $M$ & & \\
\hline 1. & Water 1L & $28^{0} \mathrm{C}$ & $105^{0} \mathrm{C}$ & $106^{0} \mathrm{C}$ & $15 \mu \mathrm{V}$ \\
\hline 2. & Water 2L & $28^{0} \mathrm{C}$ & $135^{0} \mathrm{C}$ & $135^{\circ} \mathrm{C}$ & $21 \mu \mathrm{V}$ \\
\hline 3. & Water 3L & $28^{0} \mathrm{C}$ & $145^{0} \mathrm{C}$ & $146^{\circ} \mathrm{C}$ & $23 \mu \mathrm{V}$ \\
\hline 4. & Egg & $28^{0} \mathrm{C}$ & $138^{\circ} \mathrm{C}$ & $138^{\circ} \mathrm{C}$ & $22 \mu \mathrm{V}$ \\
\hline 5. & Noodle & $28^{0} \mathrm{C}$ & $135^{\circ} \mathrm{C}$ & $135^{\circ} \mathrm{C}$ & $19 \mu \mathrm{V}$ \\
\hline 6. & $\begin{array}{l}\text { Sweet } \\
\text { potato }\end{array}$ & $28^{0} \mathrm{C}$ & $140^{\circ} \mathrm{C}$ & $141^{\circ} \mathrm{C}$ & $22 \mu \mathrm{V}$ \\
\hline 7. & Cassava & $29^{0} \mathrm{C}$ & $160^{\circ} \mathrm{C}$ & $162^{\circ} \mathrm{C}$ & $26 \mu \mathrm{V}$ \\
\hline 8. & $\begin{array}{l}\text { Bean } \\
\text { sprouts }\end{array}$ & $28^{0} \mathrm{C}$ & $120^{\circ} \mathrm{C}$ & $120^{\circ} \mathrm{C}$ & $18 \mu \mathrm{V}$ \\
\hline 9. & Potato & $28^{0} \mathrm{C}$ & $136^{0} \mathrm{C}$ & $137^{\circ} \mathrm{C}$ & $22 \mu \mathrm{V}$ \\
\hline 10. & Vegetable & $28^{0} \mathrm{C}$ & $130^{\circ} \mathrm{C}$ & $130^{\circ} \mathrm{C}$ & $20 \mu \mathrm{V}$ \\
\hline
\end{tabular}
of the test.

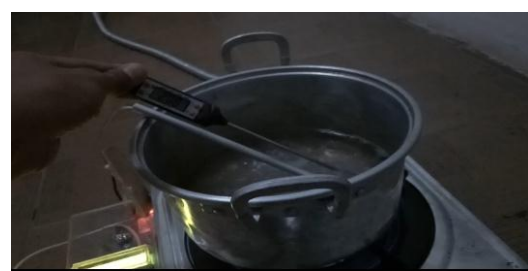

Fig. 8. Calibration of the sensors

TABLE II. RESULTS OF THERMOCOUPLE SENSOR TEST

Note:

Temperature R: Room temperature

Temperature M: Cooking temperature

Vout:Thermocouple output voltage level

According to above experiment, the eggs were $0.5 \mathrm{~kg}$ with 1.5 liter water, while for the noodle was 2 packs with 1.5 liters 
of water. The sweet potato was $1 \mathrm{~kg}$ with 2 liters of water, while the cassava was about $1 \mathrm{~kg}$ with 1.5 liters of water. The bean sprouts were $0.5 \mathrm{~kg}$ with 2 liters of water. The potatoes were $0.5 \mathrm{~kg}$ with 2 liters of water, while the vegetables were 0.4 grams with 2 liters of water.

\section{PID Method Test}

Table III shows the results of PID method test.

TABLE III. PID METHOD TEST

\begin{tabular}{|c|l|c|c|c|}
\hline No. & Ingredients & $\begin{array}{c}\text { Reference } \\
\text { Temperature }\end{array}$ & $\begin{array}{c}\text { PID } \\
\text { Temperature }\end{array}$ & $\begin{array}{c}\text { Error } \\
(\boldsymbol{\%})\end{array}$ \\
\hline 1. & Water 1 liter & $105^{\circ} \mathrm{C}$ & $113^{\circ} \mathrm{C}$ & 7.6 \\
\hline 2. & Water 2 liters & $135^{\circ} \mathrm{C}$ & $140^{\circ} \mathrm{C}$ & 3.7 \\
\hline 3. & Water 3 liters & $145^{\circ} \mathrm{C}$ & $150{ }^{\circ} \mathrm{C}$ & 3.4 \\
\hline 4. & Noodle 2 packs & $135^{\circ} \mathrm{C}$ & $142^{\circ} \mathrm{C}$ & 5.1 \\
\hline 5. & Sweet potato & $140^{\circ} \mathrm{C}$ & $148^{\circ} \mathrm{C}$ & 5.7 \\
\hline 6. & Cassava & $160^{\circ} \mathrm{C}$ & $164^{\circ} \mathrm{C}$ & 2.5 \\
\hline 7. & Egg & $138^{\circ} \mathrm{C}$ & $142^{\circ} \mathrm{C}$ & 2.8 \\
\hline 8. & Bean sprouts & $120^{\circ} \mathrm{C}$ & $125^{\circ} \mathrm{C}$ & 4.1 \\
\hline 9. & Potato & $136^{\circ} \mathrm{C}$ & $138^{\circ} \mathrm{C}$ & 1.4 \\
\hline 10. & Vegetables & $130^{\circ} \mathrm{C}$ & $133^{\circ} \mathrm{C}$ & 2.3 \\
\hline & \multicolumn{4}{|l}{} \\
\hline
\end{tabular}

Of the 10 trials using the PID method, all resulted that the temperature values could be analyzed because the entire experiment was successful. However, the thermocouple sensor value's decrease temperature worked too long. Such phenomenon made the thermocouple temperature value greater than the value of the determined set point or the reference temperature. Besides, the wind factor greatly influenced the detected thermocouple sensor temperature value. Table 3 shows that the average temperature error using the PID method was $3.86 \%$ with the lowest error value of $1.4 \%$ and the highest error value of $7.6 \%$. The error occurred because the temperature of the thermocouple sensor decreased very long and was affected by the surrounding wind. Therefore, there was a difference between the set point value and the temperature value using PID method.

\section{CONCLUSION}

\section{A. Conclusion}

In accordance to the above findings, this research concludes that MQ6 sensor can detect gas leak when the ACD value is more than 500. In this case, the buzzer will sound and the LCD will display "Dangerous" sign. The used PID method on automatic stove system can function well although the thermocouple works very slowly. Thermocouple sensor functions greatly because the calibration value is similar to the food thermometer.

\section{B. Suggestion}

This research suggests that a highly sensitive sensor needs to be used to better detect gas in LPG cylinder such as TGS2610. Another recommendation is that the use of thermocouple sensor is less accurate when there is wind surrounding the tool because it will affect the temperature results.

\section{REFERENCES}

[1] Y. Shifeng and L. Yajuan, "Research of The Harmful Gas Detection and Control System In Dairy," Proceedings of the 2nd International Symposium on Computer, Communication, Control and Automation (ISCCCA-13), Atlantic Press, 2013.

[2] X. Lina and C. Bin, "Exploring on the measurement methods of shale gas content," 3rd International Conference on Materials Engineering, Manufacturing Technology and Control (ICMEMTC 2016), Atlantic Press, 2016.

[3] H. Tianshu, L. Bo, W. Yaowei, and L. Tianci, "Research and Application of Infrared Leak Detection Technology for SF6 Equipment," 6th International Conference on Machinery, Materials and Computing Technology (ICMMCT 2018), Atlantic Press, 2018.

[4] Falohun, "Dangerous Gas Detection using an Integrated Circuit and MQ-9," Int. J. Comput. Appl. (0975 - 8887), vol. 135, no.7, pp. 30-34, February 2016.

[5] I. Pracoyo, S.D. Riyanto, and W. Hidayat, "Prototype of Automatic Light Lighting System Using DS 1307 Based on ATMega16 Microcontroler," Program Studi Teknik Elektro, Politeknik Cilacap.

[6] Saravanakumar, Raghavendra, Vignesh, and R. Elizabeth, "Embedding Realtime Multilevel Gas Leakage Control System,” Int. Res. J. Eng. and Technol. (IRJET), vol. 4, Issue: 03, pp. 1309-1312, 2017.

[7] D. Ganesh and A. Bala, "Improvement on Gas Leakage Detection and Location System Based on Wireless Sensor Network," Int. J. Eng. Dev. and Res., vol. 3, Issue 2, pp. 407-411, 2015.

[8] Srinivasan and Leela, "Gas Leakage Detection And Control," Int. J. Adv. Eng. and Res. Dev., vol. 2, Issue 3, pp 464-467, March 2015.

[9] F. Supegina and Wahyudi. "Design and Implementation of Automatic Door Alarm Systems with Arduino Based Gas Sensors," Jurusan Elektro, Universitas Mercu buana, Jakarta Barat.

[10] Denny, Gigih, and Sutejo. "Speed of Induction Motor 3.0 Controling Using PID and Field Oriented Control (FCO)," Politeknik Elektronika Negeri Surabaya - ITS.

[11] P.G. Hari. "Thermocouple Characteristics Using Matlab - simulink Software," J. ELTEK, vol. 12, no. 1, April 2014.

[12] R. Ywalitasanti. "Early detection of SMS-based LPG Safety. Jurusan Teknik Elektro," Fakultas Teknik, Universitas Dian Nuswantoro (UDINUS) Semarang. 2015. 